\title{
Development of Broad-range and Specific 16S rRNA PCR for Use in Routine Diagnostic Clinical Microbiology
}

\author{
Hyun-Chul Kim ${ }^{1,2}$, Yun-Tae Kim ${ }^{1}$, Hyogyeong Kim ${ }^{1}$, Sanghoo Lee ${ }^{1}$, Kyoung-Ryul Lee ${ }^{1}$ and Young-Jin Kim ${ }^{1 *}$ \\ ${ }^{1}$ Department of Molecular Biology, Seoul Medical Science Institute/Seoul Cinical Laboratories, Seoul 152-766, Korea \\ ${ }^{2}$ Department of Biomaterials Science and Engineering Yonsei University, Seoul 120-749, Korea
}

Received January 27, 2014 /Revised March 6, 2014 /Accepted March 6, 2014

\begin{abstract}
Broad-range and specific 16S rRNA gene PCR is used for detection and identification of bacterial pathogens in clinical specimens from patients with a high suspicion for infection. We describe the development of a broad-range and specific PCR primer, based on bacterial $16 \mathrm{~S}$ rRNA, for use in routine diagnostic clinical microbiology services. The primers were designed by using conservative regions of $16 \mathrm{~S}$ rRNA sequences from 10 strains. Ninety-eight clinical strains were isolated from clinical patient specimens. A total of 98 strains of bacteria were identified by phenotypic methods; PCR with newly designed primers and universal primers. All purified PCR products were sequenced using both forward and reverse primers on an automated DNA analyzer. In this study, we evaluated the usefulness of the newly designed primers and the universal primers for the detection of bacteria, and both these techniques were compared with phenotypic methods for bacteria detection. When we also tested 98 strains of clinical isolates with newly designed primers, about 778 bp DNA fragments were amplified and identified from all strains. Of the 98 strains, 94 strains $(95.9 \%)$ correspond in comparison with phenotypic methods. The newly designed primers showed that the identities of $98(100 \%)$ strains were the same as those obtained by universal PCR primers. The overall agreement between the newly designed primers and universal primers was $100 \%$. The primer set was designed for rapid, accurate, and cheap identification of bacterial pathogens. We think the newly designed primer set is useful for the identification of pathogenic bacteria.
\end{abstract}

Key words : $16 \mathrm{~S}$ rRNA, clinical isolates, the newly designed primers, universal primers

\section{Introduction}

Identification of bacteria in clinical microbiology is traditionally performed by isolation of the organisms and study of their phenotypic characteristics, including gram staining, morphology, culture requirements, and biochemical reactions. However, these methods of bacterial identification have major weakness [10]. First, they cannot be used for non-cultivable organisms. Second, we are occasionally faced with organisms exhibiting biochemical characteristics that do not fit into patterns of any known genus and species. Third, identification of slow-growing organisms would be extremely slow and difficult [10]. Especially, conventional methods often cannot fully characterize bacterial or fungal

\footnotetext{
*Corresponding author

Tel : +82-2-330-2011, Fax : +82-2-858-2814

E-mail : yjkim@scllab.co.kr

This is an Open-Access article distributed under the terms of the Creative Commons Attribution Non-Commercial License (http://creativecommons.org/licenses/by-nc/3.0) which permits unrestricted non-commercial use, distribution, and reproduction in any medium, provided the original work is properly cited
}

isolates, and laboratories are now relying on broad-range DNA sequencing for microorganism identification. Therefore, CLSI (Clinical and Laboratory Standards Institute) guideline suggests 16S rRNA for bacteria and ITS (Internal transcribed spacer) regions for fungi [8]. 16S rRNA gene sequences to study bacterial phylogeny and taxonomy have been by far the most common housekeeping genetic marker used for a number of reasons. These reasons include (i) its presence in almost all bacteria, often existing as a multigene family, or operons; (ii) the function of the 16S rRNA gene over time has not changed, suggesting that random sequence changes are a more accurate measure of time (evolution); and (iii) the $16 \mathrm{~S}$ rRNA gene (approximately 1,5 kb) is large enough for informatic purposes [7]. Despite its accuracy, $16 \mathrm{~S}$ rRNA gene sequence analysis lacks widespread use beyond the large and reference laboratories because of cost and technical considerations. We describe the development of a broad-range PCR primer set, based on bacterial 16S rRNA, for use in the routine diagnostic clinical microbiology service.

The purpose of this study was to evaluate the utility of newly designed $16 \mathrm{~S}$ rRNA primers in a clinical microbiology 
laboratory by comparing it with identification by universal PCR primers and the phenotypic methods.

\section{Materials and Methods}

\section{Bacterial strains and DNA isolation}

For the specificity of conventional PCR assay with designed primer, it was verified using strains of both American Type Culture Collection (ATCC; Manassas, VA, USA) reference and clinical origins. 20 strains obtained from the ATCC, were used in this study. And 98 clinical (50 gram-negative and 48 gram-positive) strains were isolated from patient specimens. Bacterial strains were cultured on sheep blood or chocolate agar depending upon the specific growth requirement of each species. For identification, Vitek system (bioMerieux Vitek, NC, USA) and several conventional biochemical methods were used for identification of the bacterial strains [11]. Bacterial DNA was prepared from collected bacteria samples using the G-spin ${ }^{\mathrm{TM}}$ for Bacteria Genomic DNA Extraction Kit according to the manufacturer's instructions (Intron Biotechnology, Seoul, Korea).

\section{Conventional PCR assay}

The sequences of the PCR primers that were evaluated in this study to detect broad bacteria species are all shown in Table 1. Used primer pairs are 2 primer sets. One primer set was 9F (5'-ATCCTGGCTCAGATTGAACG-3'), 767R (5'-CTAATCCTGTTTGCTCCCCA-3'). These were designed with highly conserved regions from the $16 \mathrm{~S}$ rRNA gene sequences of variable species. Conserved regions were confirmed by CLUSTALW2 software. And the other one used universal primer pair: $\mathrm{F}$ (5'-AGAGTTTGATCCTGGCTCAG3'), R (5'- GGTTACCTTGTTACGACTT-3') [7, 8, 10]. All oligonucleotides were provided from the Bioneer (Daejeon, Korea). DNA was amplified in $20 \mu \mathrm{l}$ reaction mixture consisting of $2 \mu \mathrm{l}$ of $10 \times$ PCR buffer, $1 \mu \mathrm{l}$ of $2 \mathrm{mM}$ dNTP, $1 \mu \mathrm{l}$ of $10 \mu \mathrm{M}$ forward primer, $1 \mu \mathrm{l}$ of $10 \mu \mathrm{M}$ reverse primer, 13 $\mu \mathrm{l}$ of DW, and $0.25 \mathrm{U}$ of Super-Therm Gold Taq DNA polymerase (JMR Holdings, Kent, UK). The conditions for ampli- fication of universal primer were pre-denaturation at $95^{\circ} \mathrm{C}$ for $12 \mathrm{~min}, 35$ cycles of denaturation at $95^{\circ} \mathrm{C}$ for $30 \mathrm{sec}$, annealing at $60^{\circ} \mathrm{C}$ for $40 \mathrm{sec}$, and extension at $72^{\circ} \mathrm{C}$ for $1 \mathrm{~min}$, followed by a final elongation step at $72^{\circ} \mathrm{C}$ for $10 \mathrm{~min}$. And another one with designed primer were subjected to $35 \mathrm{cy}$ cles of amplification with denaturation at $95^{\circ} \mathrm{C}$ for $30 \mathrm{sec}$, annealing at $53^{\circ} \mathrm{C}$ for $40 \mathrm{sec}$, and extension at $72^{\circ} \mathrm{C}$ for 1 $\mathrm{min}$, followed by a final elongation step at $72^{\circ} \mathrm{C}$ for $5 \mathrm{~min}$. After amplification, $6 \mu \mathrm{l}$ aliquot of each amplication product was analyzed using electrophoresis on $1 \%$ agarose gels cast and ran in 0.5× TAE buffer. A 100 bp maker (Cosmogenetech, Seoul, Korea) was included in the gel. Gel was stained with ethidium bromide and visualized using transmitted ultraviolet illumination and photographed using gel documentation system.

\section{DNA sequencing and analysis}

The PCR products were directly sequenced and analyzed using an ABI 3130XL DNA sequencers (Applied Biosystems, USA) and ABI sequencing Analysis Software. To eliminate errors caused by amplification artifacts, the forward and reverse sequences of each $16 \mathrm{~S}$ rRNA gene sequences were determined for products from at least two independent PCRs. The sequences of the PCR products were compared with known $16 \mathrm{~S}$ rRNA gene sequences in NCBI GenBank (http://www.ncbi.nlm.nih.gov/genbank/).

\section{Results}

The 9F/767R bacterial primer set was designed from a conserved region of the 16S rRNA gene, which is located between the universal bacterial primer set (Fig. 1, Table 1). Bacterial 16S rRNA sequences were amplified from type strians and clinical isolates. We describe new primer set (9F/767R) and universal primer set (8F/1492R) that may be used to amplify DNA from many different species of microorganism, and use this DNA to identify the organisms.

For each sample, two different PCR products, using 9F/ $767 \mathrm{R}$ and $8 \mathrm{~F} / 1492 \mathrm{R}$ primers, were independently processed.

Table 1. Synthetic oligonucleotide used as primer for PCR

\begin{tabular}{|c|c|c|c|}
\hline Oligo name & Sequence $\left(5^{\prime} \rightarrow 3^{\prime}\right)$ & Amplicon size (bp) & Reference \\
\hline $\begin{array}{c}8 \mathrm{~F} \\
1492 \mathrm{R}\end{array}$ & $\begin{array}{c}\text { AGAGTTTGATCCTGGCTCAG } \\
\text { GGTTACCTTGTTACGACTT }\end{array}$ & 1500 & $2,3,5$ \\
\hline $\begin{array}{c}9 \mathrm{~F} \\
767 \mathrm{R}\end{array}$ & $\begin{array}{l}\text { ATCCTGGCTCAGATTGAACG } \\
\text { CTAATCCTGTTTGCTCCCCA }\end{array}$ & 778 & In this study \\
\hline
\end{tabular}




Pseudomonas
Burkholderia
Enterobacter
Klebsiella
Escherichia
Shigella
Salmonella
Proteus
Enterococcus
Staphylococcus

Pseudomonas
Burkholderia
Enterobacter
Klebsiella
Escherichia
Shigella
Salmonella
Proteus
Enterococcus
Staphylococcus

Pseudomonas Burkholderia Enterobacter Klebsiella Escherichia Shigella Salmonella Proteus Enterococeus Staphylocoecus

Pseudomonas
Burkholderia
Enterobacter
Klebsiella
Escherichia
Shigella
Salmonella
Proteus
Enterococcus
Staphylococeus

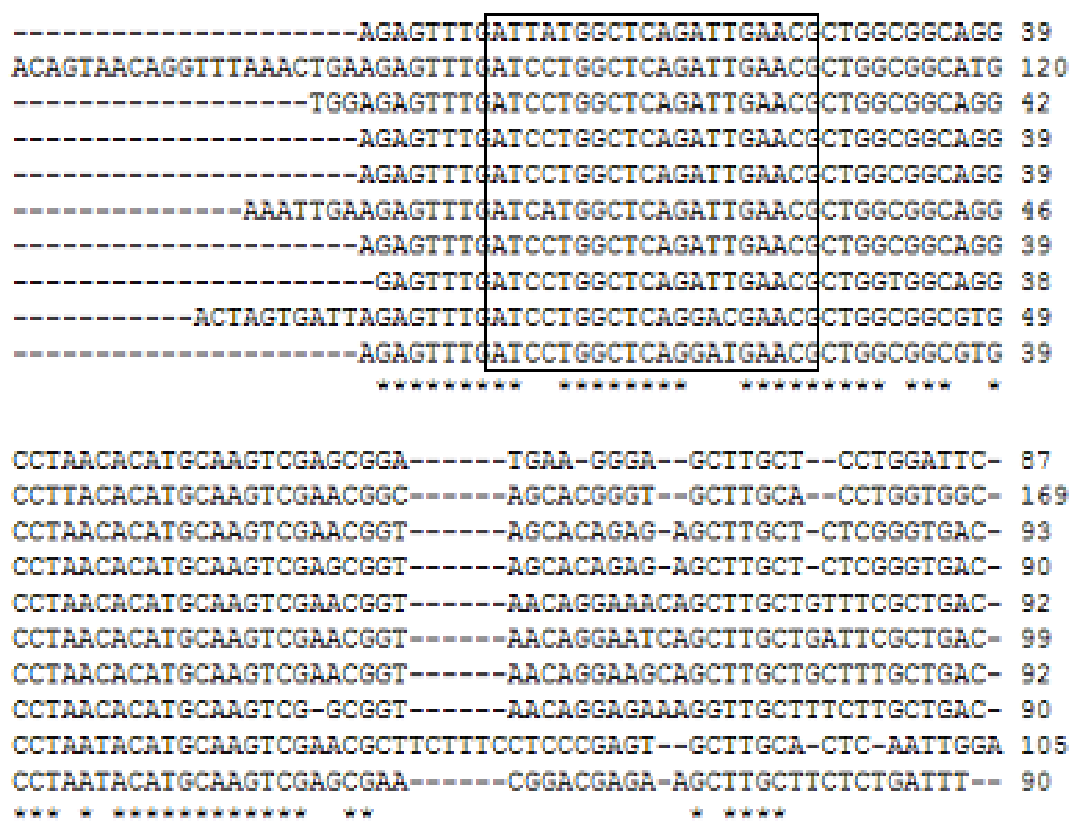

TGTGTAGCGGTGAAATGCGTAGATATAGGAAGGAACACCAGTGGCGAAGGCGACCACCTG 728 CGTGTAGCAGTGNAITGCGTAGAGATGTGGAGGATACCGNTGGCGNAGGCAGCCCCCTG 811 GGIGIAGCGGIGAAATGCGIAGAGATCTGGAGGAMTACCGGIGGCGAAGGCGGCCCCCTG 735 GGTGTAGCGGTGAAATGCGTAGAGATCTGGAGGAATACCGGTGGCGAAGGCGGCCCCCTG 732 GGTGTAGCGGTGAAATGCGTAGAGATCTGGAGGAATACCGGTGGCGAAGGCGGCCCCCTG 734 GGTGTAGCGGTGNATGCGTAGAGATCTGGRGGATMCCGGTGGCGARGGCGGCCCCCTG 741 GGIGIAGCGGIGAAAIGCGTAGAGATCTGGAGGAATACCGGIGGCGAAGGCGGCCCCCTG 734 TGTGTAGCGGTGAAATGCGTAGAGATGTGGAGGAATACCGGTGGCGAAGGCGGCCCCCTG 732 TGTGTAGCGGTGAAATGCGTAGATATATGGAGGAACACCAGTGGCGAAGGCGGCTCTCTG 762

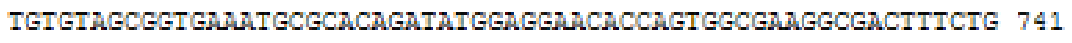
$* * * * * * * * * * * * * * * * * * * * * * * * * * * * * * * * * * * * * * * * * * *$

GACTGATACTGACACTGAGGTGCGAAAGCETGGGGAGCARACAGGATTAGATACCCTGGT 788 GGCCAMTACTGACGCTCATGCACGARAGC ITGGGGACANACAGGATTAGATACCCTGGT 871 GACAAAGACTGACGCTCAGGIGCGAAAGC IGGGGAGCAAACAGGATTAGATACCCTGGI 795 GACAAAGACTGACGCTCAGGTGCGAAAGCOIGGGGAGCAAACAGGATTAOSTACCCTGGT 792 GACGAAGACTGACGCTCAGGTGCGAAAGC TGGGGAGCARACAGGATTAEATACCCTGGT 794

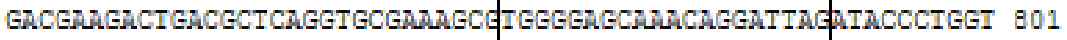
GACAAAGACTGACGCTCAGGTGCGAAAGCOIGGGGAGCAAACAGGATTAGATACCCTGGI 794 GACAAAGACTGACGCTCAGGTGCGAAAGCOTGGGGAGCAAACAGGATTAGATACCCTGGT 792 GTCTGTAACTGACGCTGAGGCTCGAAAGCOTGGGGAGCARACAGGATTAGATACCCTGGT 822 GTCTGTACTGACGCTGATGTGCGARAGC IGGGGTCMACAGGATTAGATACCCTGGT 801 ** ****************************************

Fig. 1. Alignment of sequences in the region of the 16S rRNA genes for P. aeruginosa (EF079669), B. cepacia (GQ359110), E. cloacat (GU191924), K pneumoniae (HQ200406), E. coli (FJ823386), S. flexneri (EU009189), S. typhi (Z47544), P. mirabilis (HM771658), E. faecalis (AY692453), S. aureus (AB634830), (lines 1 to 10, respectively). Square boxes represent primers newly designed from $16 \mathrm{~S}$ rRNA sequences.

Amplification using the universal primer pair generated a single DNA fragment of approximately 1,492 bp (Fig. 2A). Amplification using the new primer pair generated DNA bands at about 778 bp (Fig. 2B). This pairs were used to $16 \mathrm{~S}$ rRNA amplification from the 20 species type strains (Acinetobacter lwoffii ATCC 17925, Bacillus subtilis ATCC 6633,
Brevibacilus brevis ATCC 8246, Enterobacter cloacae ATCC 700323, Enterobacter sakazakii ATCC 29544, Enterococcus casseliflavus ATCC 700327, Enterococcus faecalis ATCC 51299, Enterococcus faecalis ATCC 29212, Escherichia coli ATCC 25922, Escherichia coli O157:H7 ATCC 43888, Klebsiella pneumoniae ATCC 13883, Proteus mirabilis ATCC 7005, Providencia alcalifa- 
A

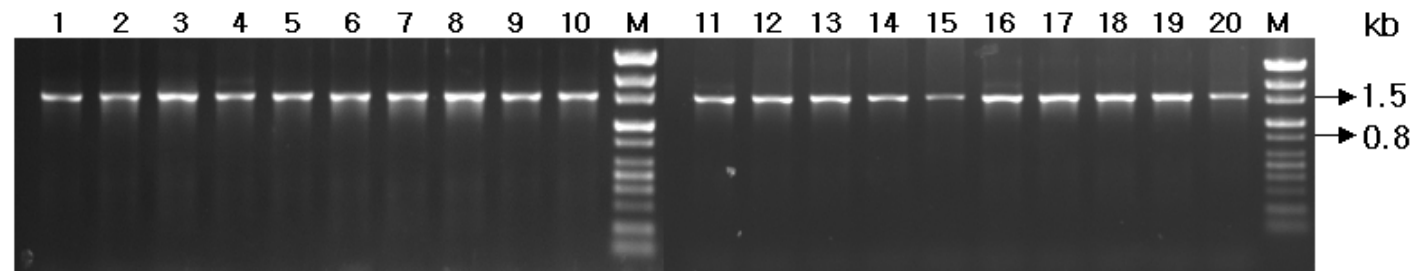

B

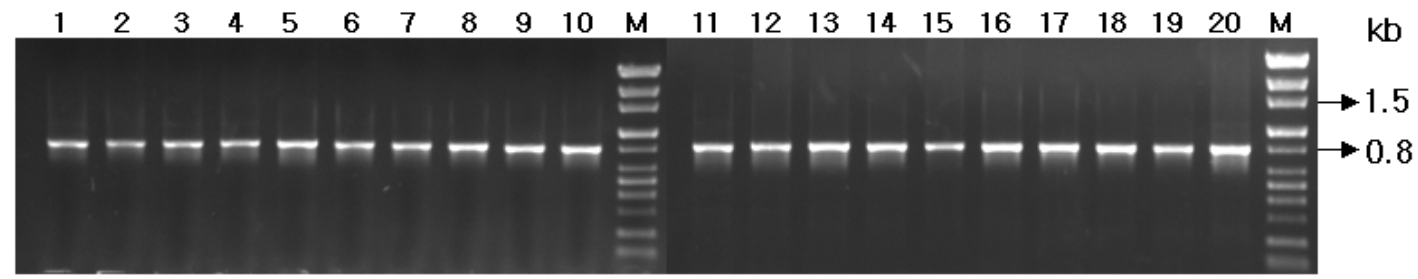

Fig. 2. PCR products in a $1 \%$ agarose gel for the 20 bacterial species tested with universal primer and the newly designed primers. (A) Universal PCR with primers 8F and 1492R (amplicon size: 1,492 bp), (B) PCR with newly designed primers 9F and 767R (amplicon size: 778 bp), Lanes: M, DNA size markers; 1, Acinetobacter Iwoffii ATCC 17925; 2, Bacillus subtilis ATCC 6633; 3, Brevibacilus brevis ATCC 8246; 4, Enterobacter cloacae ATCC 700323; 5, Enterobacter sakazakii ATCC 29544; 6, Enterococcus casseliflavus ATCC 700327; 7, Enterococcus faecalis ATCC 51299; 8, Enterococcus faecalis ATCC 29212; 9, Escherichia coli ATCC 25922; 10, Escherichia coli O157:H7 ATCC 43888; 11, Klebsiella pneumoniae ATCC 13883;12, Proteus mirabilis ATCC 7005; 13, Providencia alcalifaciens ATCC 51902; 14, Pseudomonas aeruginosa ATCC 9027; 15, Pseudomonas aeruginosa ATCC 27853; 16, Salmonella typhimurium ATCC 1925; 17, Staphylococcus aureus ATCC 25923; 18, Streptococcus pneumoniae ATCC 49619; 19 , Streptococcus pyogenes ATCC 19615; 20, Vibrio parahaemolyticus NCCP 10511.

ciens ATCC 51902, Pseudomonas aeruginosa ATCC 9027, Pseudomonas aeruginosa ATCC 27853, Salmonella typhimurium ATCC 1925, Staphylococcus aureus ATCC 25923, Streptococcus pneumoniae ATCC 49619, Streptococcus pyogenes ATCC 19615, Vibrio parahaemolyticus NCCP 10511), all of which were amplified successfully and showed no additional bands. The newly designed primers showed about 778 bp size DNA band (PCR product) in the 98 clinical isolated strains.

Using universal primers, the $16 \mathrm{~S}$ rRNA gene PCR amplification of the 98 isolates showed about 1,492 bp. Using new primers, the $16 \mathrm{~S}$ rRNA gene PCR amplification of the 98 isolates was successful, yielding target bands at about $778 \mathrm{bp}$. Furthermore, DNA sequencing of the corresponding PCR products using the same oligonucleotides as sequencing primers posed no problems. Purified PCR products were directly sequenced in both forward and reverse directions using the same primers as for PCR. Table 1 shows bacteria identification using either the universal primer or the newly designed $16 \mathrm{~S}$ rRNA primers. The 16s rRNA sequence of type strains were compared with the universal primers and newly designed $16 \mathrm{~S}$ rRNA primers. The nucleotide similarity values were calculated, and similarity values were determined using the BLAST program at NCBI website. An observed percentage difference is the number of base mismatches between two aligned sequences, as determined. Obtained full sequences showed approximately average
99.74\% (99.4 99.8\%) identification with the database sequences using universal primers, indicating that correct amplification had been achieved. Also, average bacteria identification by new primers were $99.72 \%$ (Table 2). All strains, except Bacillus subtilis, analysed sequences revealed identification above 99\% (99.2 100\%), Bacillus subtilis is identified as having a high rate of $98.9 \%$. The identities of 19 type strains were the same as those obtained by universal primers and the rate of identification is above $99 \%$. For all 20 type strains, there was $<1.1 \%$ difference between the $16 \mathrm{~S}$ rRNA gene sequences of the type strains and the most closely matched sequence in the GenBank (Table 2).

Analysis of the 20 strains sequences using the newly designed primers by $16 \mathrm{~S}$ rRNA-based bacterial identification database showed that the identities of 20 strains were the same as those obtained by universal $16 \mathrm{~S}$ rRNA gene sequencing. In other words, twenty of 20 strains were identified as the same species by newly designed primers, in agreement with the naming by the ATCC or NCCP. Then, we evaluated the usefulness of this primer in the identification of isolates clinically significant bacterial strains that showed phenotypic identification methods. A total of 98 bacterial strains were tested by molecular method including the newly designed primers with universal primers and phenotypic methods. The identification of 98 strains analyzed and the alignment tool used can also affect the comparison of 
Table 2. Analysis of DNA sequences of type strains identified using $16 \mathrm{~S}$ rRNA bacteria database

\begin{tabular}{|c|c|c|c|c|c|}
\hline \multirow[b]{2}{*}{ Organism } & \multirow[b]{2}{*}{ Strain no. } & \multicolumn{2}{|c|}{$\begin{array}{l}\text { Identification using universal primer } \\
\left.\qquad(1,492 \mathrm{bp})^{\mathrm{a}}\right)\end{array}$} & \multicolumn{2}{|c|}{$\begin{array}{l}\text { Identification using new } 9 \mathrm{~F} / 767 \mathrm{R} \\
\text { primer }(778 \mathrm{bp})^{\text {a) }}\end{array}$} \\
\hline & & $\begin{array}{l}\text { No. of base differences } \\
\text { between two aligned } \\
\text { sequences }(\%)\end{array}$ & $\begin{array}{c}\text { Identification } \\
(\%)\end{array}$ & $\begin{array}{l}\text { No. of base differences } \\
\text { between two aligned } \\
\text { sequences }(\%)\end{array}$ & $\begin{array}{c}\text { Identification } \\
(\%)\end{array}$ \\
\hline Acinetobacter Iwoffii & ATCC 17925 & $8(0.6)$ & 99.4 & $2(0.3)$ & 99.7 \\
\hline Bacillus subtilis & ATCC 6633 & $7(0.5)$ & 99.5 & $8(1.1)$ & 98.9 \\
\hline Brevibacilus brevis & ATCC 8246 & $6(0.4)$ & 99.6 & $6(0.8)$ & 99.2 \\
\hline Enterobacter cloacae & ATCC 700323 & $4(0.3)$ & 99.7 & $3(0.4)$ & 99.6 \\
\hline Enterobacter sakazakii & ATCC 29544 & $3(0.2)$ & 99.8 & $0(0)$ & 100 \\
\hline Enterococcus casseliflavus & ATCC 700327 & $1(0.1)$ & 99.9 & $1(0.1)$ & 99.9 \\
\hline Enterococcus faecalis & ATCC 51299 & $3(0.2)$ & 99.8 & $1(0.1)$ & 99.9 \\
\hline Enterococcus faecalis & ATCC 29212 & $1(0.1)$ & 99.9 & $0(0)$ & 100 \\
\hline Escherichia coli & ATCC 25922 & $5(0.4)$ & 99.6 & $2(0.3)$ & 99.7 \\
\hline Escherichia coli O157:H7 & ATCC 43888 & $3(0.2)$ & 99.8 & $5(0.7)$ & 99.3 \\
\hline Klebsiella pneumoniae & ATCC 13883 & $3(0.2)$ & 99.8 & $0(0)$ & 100 \\
\hline Proteus mirabilis & ATCC 7005 & $2(0.1)$ & 99.9 & $3(0.3)$ & 99.6 \\
\hline Providencia alcalifaciens & ATCC 51902 & $2(0.1)$ & 99.9 & $1(0.1)$ & 99.9 \\
\hline Pseudomonas aeruginosa & ATCC 9027 & $2(0.2)$ & 99.8 & $2(0.3)$ & 99.7 \\
\hline Pseudomonas aeruginosa & ATCC 27853 & $6(0.4)$ & 99.6 & $1(0.1)$ & 99.9 \\
\hline Salmonella typhimurium & ATCC 1925 & $7(0.5)$ & 99.5 & $3(0.4)$ & 99.6 \\
\hline Staphylococcus aureus & ATCC 25923 & $3(0.2)$ & 99.8 & $1(0.1)$ & 99.9 \\
\hline Streptococcus pneumoniae & ATCC 49619 & $1(0.1)$ & 99.9 & $0(0)$ & 100 \\
\hline Streptococcus pyogenes & ATCC 19615 & $2(0.1)$ & 99.9 & $1(0.1)$ & 99.9 \\
\hline Vibrio parahaemolyticus & NCCP 10511 & $5(0.3)$ & 99.7 & $2(0.3)$ & 99.7 \\
\hline
\end{tabular}

a) Analysis using database of GenBank

sequences. An observed percentage is the number of matches or mismatches between blasted sequences, as determined. Four of 98 isolated strains showed a considerable number of mismatches with clinical isolates in phenotypic method. Newly designed PCR primers and universal PCR primers analysis of the isolates revealed same results for 98 clinical isolates, while in 4 isolates, phenotypic method were inconsistent (Table 3). It reaffirms the $16 \mathrm{~S}$ rRNA genes amplification of the 4 isolates showed bands at about 1,492 bp and $778 \mathrm{bp}$, respectively. Four strains of incorrect identity (one of Escherichia coli, one of Stapylococcus aureus, one of Corynebacterium striatum and one of Streptococcus sp.) were studied to assess and compare newly designed PCR primers and universal PCR primers by $16 \mathrm{~S}$ rRNA-based identification of bacteria. The 4 strains (E. coli, $S$. aureus, C. striatum, Streptococcus sp.) has been identified as a strain of Citrobacter freundii, Stapylococcus saprophyticus, Corynebacterium confusum, Arthrobacter cumminsii, respectively (Table 3). After all, identification of phenotypic method of 4 isolates was not discriminative enough. However, new primers and universal primers of these 98 isolates were compared to the known $16 \mathrm{~S}$ rRNA gene sequences in the GenBank, yielded the cor- rect identity, with good discrimination. The overall agreement between the newly designed primers and universal primers were $100 \%$. Therefore, the newly designed primers of identification have the advantage over phenotypic methods of identification, the newly designed primers $16 \mathrm{~S}$ rRNA-based, is investigation and approach focused on identifying to solved the problem of phenotypic method.

In this case, in fact, bacteria identification can be detected by the use of the newly designed PCR primers, instead of the "universal" primers 8F/1492R.

\section{Discussion}

Clinically significant strains should be identified at the species level by a reliable and reproducible method to provide a better understanding of pathogenic potential of various species. Phenotypic methods for identification of strains appear to be unreliable. The purpose of the present study was to compare commonly used phenotypic methods, the Vitek system and PCR amplicon-sequencing based methods targeting the 16S rRNA gene.

In this study, we evaluated the usefulness of the newly 
Table 3. Identification of gram-negative and gram-positive bacteria in clinical isolates using two primer sets

\begin{tabular}{|c|c|c|c|c|c|}
\hline \multirow[b]{2}{*}{$\begin{array}{l}\text { Identified strains by } \\
\text { phenotypic methods }{ }^{a}\end{array}$} & \multirow[b]{2}{*}{$\begin{array}{l}\text { Total no. } \\
\text { of strains }\end{array}$} & \multicolumn{2}{|c|}{ Universal primer $(1,492 \mathrm{bp})$} & \multicolumn{2}{|c|}{ 9F/767R primer $(778 \mathrm{bp})$} \\
\hline & & $\begin{array}{c}\text { Matche with } \\
\text { identified strains } \\
(\%)\end{array}$ & $\begin{array}{c}\text { Mismatch with } \\
\text { identified strains } \\
(\%)\end{array}$ & $\begin{array}{c}\text { Matche with } \\
\text { identified strains } \\
(\%)\end{array}$ & $\begin{array}{c}\text { Mismatch with } \\
\text { identified strains } \\
(\%)\end{array}$ \\
\hline E. coli & 28 & $27(96.4)$ & $1^{\mathrm{b})}(3.6)$ & $27(96.4)$ & $1^{\text {b) }}(3.6)$ \\
\hline$K$ pneumoniae & 7 & $7(100)$ & & $7(100)$ & \\
\hline Serratia marcescens & 6 & $6(100)$ & & $6(100)$ & \\
\hline Morganella morganii ssp morganii & 2 & $2(100)$ & & $2(100)$ & \\
\hline Proteus mirabilis & 4 & $4(100)$ & & $4(100)$ & \\
\hline Providencia rettgeri & 1 & $1(100)$ & & $1(100)$ & \\
\hline Citrobacter braakii & 1 & $1(100)$ & & $1(100)$ & \\
\hline Acinetobactor baumanii complex & 1 & $1(100)$ & & $1(100)$ & \\
\hline Stapylococcus aureus & 10 & $9(90)$ & $1^{c)}(10)$ & $9(90)$ & $1^{c)}(10)$ \\
\hline Enterococcus faecalis & 8 & $8(100)$ & & $8(100)$ & \\
\hline Streptococcus agalactiae & 8 & $8(100)$ & & $8(100)$ & \\
\hline Stapylococcus haemolyticus & 3 & $3(100)$ & & $3(100)$ & \\
\hline Enterococcus faecium & 3 & $3(100)$ & & $3(100)$ & \\
\hline Corynebacterium striatum & 2 & $1(50)$ & $1^{\text {d) }}(50)$ & $1(50)$ & $1^{\text {d) }}(50)$ \\
\hline Staphylococcus pneumoniae & 1 & $1(100)$ & & $1(100)$ & \\
\hline Staphylococcus lugdunensis & 1 & $1(100)$ & & $1(100)$ & \\
\hline Stapylococcus hominis & 1 & $1(100)$ & & $1(100)$ & \\
\hline Stapylococcus capitis ssp. capitis & 1 & $1(100)$ & & $1(100)$ & \\
\hline Stapylococcus epidermidis & 1 & $1(100)$ & & $1(100)$ & \\
\hline Streptococcus dysgalacitae ssp. equisimilis & 1 & $1(100)$ & & $1(100)$ & \\
\hline Streptococcus pyogenes & 1 & $1(100)$ & & $1(100)$ & \\
\hline Streptococcus sp. & 1 & & $1^{\mathrm{e})}(100)$ & & $1^{\mathrm{e})}(100)$ \\
\hline Streptococcus mitis & 1 & $1(100)$ & & $1(100)$ & \\
\hline Streptococcus anginosus & 1 & $1(100)$ & & $1(100)$ & \\
\hline Corynebacterium pseudodiphtherigoicum & 1 & $1(100)$ & & $1(100)$ & \\
\hline Corynebacterium urealyticum & 1 & $1(100)$ & & $1(100)$ & \\
\hline Staphylococcus caprae & 1 & $1(100)$ & & $1(100)$ & \\
\hline Streptococcus gordonii & 1 & $1(100)$ & & $1(100)$ & \\
\hline
\end{tabular}

\footnotetext{
${ }^{a}$ Vitek system (bioMerieux Vitek) was used for identification of 50 clinical isolates of 50 gram-negative and 30 clinical isolates of 48 gram-positive (except clinical isolates of 10 Staphylococcus aureus and 8 Streptococcus agalactiae) $10 \mathrm{~S}$. aureus clinical isolates were identified using the biochmical test (catalase, coagulase test, DNase, Mannitol salt agar), and 8 S. agalactiae clinical isolates were identified using the Pastorex Strep test (Bio-Rad, Hercules, CA, USA).

${ }^{b)}$ Citrobacter freundii

c) Stapylococcus saprophyticus

d) Corynebacterium confusum

e) Arthrobacter cumminsii
}

designed primers and of universal primers (8F and 1492R) for identification of bacteria, and both these techniques were compared with phenotypic methods (Vitek, biochemical test, and streptex) for bacteria identification. Ninety-eight clinical strains (50 gram-negative and 48 gram-positive) were isolated from clinical patient specimens. A total 98 strains of bacteria were identified by molecular method (PCR) with newly designed primers and universal primers and phenotypic methods.

Nucleotide sequences of PCR new primers (9F and 767R) designed from the universally conserved amino acid sequences of the $16 \mathrm{~S}$ rRNA gene from 10 type strains (Acinetobacter Iwoffii, Bacillus subtilis, Brevibacilus brevis, Enterobacter cloacae, Enterobacter sakazakii, Enterococcus casseliflavus, Enterococcus faecalis, Enterococcus faecalis, Escherichia coli, Escherichia coli O157, Klebsiella pneumoniae, Proteus mirabilis, Providencia alcalifaciens, Pseudomonas aeruginosa, Pseudomonas aeruginosa, Salmonella typhimurium, Staphylococcus aureus, Streptococcus pneumoniae, Streptococcus pyogenes, Vibrio parahaemolyticus). Each strain sequences were aligned using ClustalW. And 
then the specific PCR primers for type strains were designed using the Primer3Plus (Fig. 1, Table 1).

DNA obtained from ATCC standard control strains was examined by the universal primers and newly designed primers (Fig. 2). All of these DNA samples generated the universal PCR product of the expected 1,492 bp size (Fig. 2A). The newly designed primers PCR band of approximately 778 bp was also produced (Fig. 2B).

Table 2 shows identification using either the universal primers or the newly designed 16S rRNA primers. We used BLAST to compare the sequence of PCR product with known nucleotide sequences of type strains in the database. Observed percentage difference is the number of base mismatches between two aligned sequences. Rates of correct identification by the universal primers and new primers were 99.74(99.4 99.9\%) and 99.72(98.9 100\%), respectively (Table 2). When all type strains were considered, that new primer have very similar rate to universal primer. We found that all of the type strain sequences they generated had an identical perfect matching sequence when analyzed by new primers. In other words, twenty of 20 strains were identified as the same species by newly designed primer, in agreement with the naming by the ATCC or NCCP.

In this study, we evaluated the utility of newly designed primer as a means to identify 98 isolates obtained from clinical sources. Surveys looked at the feasibility of identifying medically important bacteria using newly designed primers. When we also tested 98 strains of clinical isolates with newly designed primers and universal primers, DNA fragment was amplified and was identified from all strains. Phenotypic identification including Vitek system, biochemical test, and strep test were performed in the 98 isolates. 16S rRNA genes using two primer sets were amplified by PCR, sequencing and then the sequence was put in GenBank BLAST to compare with database in NCBI.

Of the total 98 strains, 94 strains $(95.9 \%)$ correspond in comparison with phenotypic methods. $4(4.1 \%)$ isolates were misidentified at phenotypic methods. The newly designed primers showed that the identities of $98(100 \%)$ strains were the same as those obtained by universal PCR primers (Table 3 ). The overall agreement between the newly designed primers and universal primers were $100 \%$. Newly designed PCR primers and universal PCR primers analysis of the clinical isolates revealed same results for 50 gram negative isolates, while phenotypic result of 1 isolate was inconsistent. One Citrobacter freundii strain was incorrectly identified as
E. coli with the phenotypic methods (Table 3).

Even if $16 \mathrm{~S}$ rRNA gene sequencing is highly useful in regards to bacterial identification, it has low phylogenetic power at the species level and poor discriminatory power for some genera $[1,6,9]$, and DNA relatedness studies are necessary to provide absolute resolution to these taxonomic problems. Previously, it was reported that the type strains of Edwardsiella species exhibit 99.35 to $99.81 \%$ similarity to each other, and yet these three species are clearly distinguishable biochemically and by DNA homology (28 to $50 \%$ relatedness) [4].

The misidentification rate was higher with the Vitek than with the sequence. These misidentifications did lead to errors in interpretation of clinical isolates. However, in this study, Newly designed PCR primers and universal PCR primers for $K$ pneumoniae, Serratia marcescens, Morganella morganii ssp morganii, Proteus mirabilis, Citrobacter braakii and Acinetobactor baumanii complex showed good agreement with phenotypic methods. With the exception of 3 isolates ( $S$. aureus, Corynebacterium striatum, Streptococcus sp.), 45 isolates showed good agreement with phenotypic methods. A higher percentage of species identifications were obtained using newly designed primers and universal primers results than phenotypic methods.

All strains except 8 E. faecalis, 8 Streptococcus agalactiae, 3 S. haemolyticus, 3 E. faecium, 1 S. pneumoniae, 1 S. lugdunensis, 1S. hominis, 1 Stapylococcus capitis ssp. Capitis, 1 Stapylococcus epidermidis, 1 Streptococcus dysgalacitae ssp. Equisimilis, 1 Streptococcus pyogenes, 1 Streptococcus mitis (viridans strep), 1 Streptococcus anginosus, 1 Corynebacterium pseudodiphtherigoicum, 1 Corynebacterium urealyticum, 1 Staphylococcus caprae, and 1 Streptococcus gordonii, phenotypic results matched molecular methods (New primer and universal primer).

Four strains of incorrect identity (one of Escherichia coli, one of Stapylococcus aureus, one of Corynebacterium striatum and one of Streptococcus sp.) were studied to assess and compare newly designed PCR primers and universal PCR primers by $16 \mathrm{~S}$ rRNA-based identification of bacteria. 4 strains, E. coli, S. aureus, C. striatum, Streptococcus sp., has been identified as a strain of Citrobacter freundii, Stapylococcus saprophyticus, Corynebacterium confusum, Arthrobacter cumminsii, respectively. The overall agreement between the newly designed primers and universal primers were $100 \%$.

Therefore, the newly designed primers for identification have the advantage over phenotypic methods, the newly designed primers $16 \mathrm{~S}$ rRNA-based, is investigation and ap- 
proach focused on identifying to solved the problem of phenotypic method.

The primer set was designed for rapid and accurate identification of bacterial pathogens. We think the newly designed primer set is useful for the identification of pathogenic bacteria. In this case, in fact, bacteria identification can be detected by the use of the newly designed PCR primers, instead of the "universal" primers 8F/1492R.

Some bacteria are difficult to identify with phenotypic identification schemes commonly used outside reference laboratories. $16 \mathrm{~S}$ rRNA-based identification of bacteria potentially offers a useful alternative when phenotypic characterization methods fail. However, as yet, the usefulness of $16 \mathrm{~S}$ rRNA sequence analysis in the identification of conventionally unidentifiable isolates has not been evaluated with a large collection of isolates. In this study, we evaluated the utility of $16 \mathrm{~S}$ rRNA sequencing as a means to identify a collection of isolates obtained from clinical sources.

The sensitivity and specificity for pathogens identification were compared among different methods. 98 clinical specimens from different sources underwent phenotypic identification and molecular identification using 16S rRNA universal PCR primers and the newly designed primers. As results, our new primers have the usefulness.

\section{Acknowledgment}

This work was supported by Seoul Medical Science Institute in 2013.

\section{References}

1. Bosshard, P. P., Zbinden, R., Abels, S., Bo"ddinghaus, B., Altwegg, M. and Bo"ttger, E. C. 2006. $16 \mathrm{~S}$ rRNA gene sequencing versus the API $20 \mathrm{NE}$ system and the Vitek 2 ID-GNB card for identification of nonfermenting gramnegative bacteria in the clinical laboratory. J Clin Microbiol
44, 1359-1366.

2. Brandl, M. T., Quinones, B. and Lindow, S. E. 2001. Heterogeneous transcription of an indoleacetic acid biosynthetic gene in Erwinia herbicola on plant surfaces. Proc Natl Acad Sci USA 98, 3454-3459.

3. Hidetoshi, U., Kumiko, K.-T. and Kouichi, O. 1999. Microbial diversity in marine sediments from Sagami Bay and Tokyo Bay, Japan, as determined by $16 \mathrm{~S}$ rRNA gene analysis. Microbiology 145, 3305-3315.

4. John, M. J. and Sharon, L. A. 2007. 16S rRNA gene sequencing for bacterial identification in the diagnostic laboratory: pluses, perils, and pitfalls. J Clin Microbiol 45, 2761-2764.

5. Les, D. and Thomas, M. S. 2007. Performance of the translational apparatus varies with the ecological strategies of bacteria. J Bacteriol 189, 3237-3245.

6. Mignard, S. and Flandrois, J. P. 2006. 16S rRNA sequencing in routine bacterial identification: a 30-month experiment. J Microbiol Methods 67, 574-581.

7. Patel, J. B. 2001. 16S rRNA gene sequencing for bacterial pathogen identification in the clinical laboratory. Mol Diagn 6, 313-321.

8. Petti, C. A., Bosshard, P. P., Brandt, M. E., Clarridge, J. E. III., Feldblyum, T. V., Foxall, P., Furtado, M. R., Pace, N. and Procop, G. 2008. Interpretive criteria for identification of bacteria and fungi by DNA target sequencing, approved guideline document MM18-A, 28. Wayne, PA: Clinical and Laboratory Standards Institute.

9. Rudolf, I. A., Wolfgang, L. and Karl-heinz, S. 1995. Phylogenetic identification and in situ detection of individual microbial cells without cultivation. Microbiol Rev 59, 143-169.

10. Woo, P. C., Ng, K. H., Lau, S. K., Yip, K. T., Fung, A. M., Leung, K. W., Tam, D. M., Que, T. L. and Yuen, K. Y. 2003. Usefulness of the microSeq $50016 S$ ribosomal DNA-based bacterial identification system for identification of clinically significant bacterial isolates with ambiguous biochemical profiles. J Clin Microbiol 41, 1996-2001.

11. Woo, P. C., To, A. P., Lau, S. K., Fung, A. M. and Yuen, K. Y. 2004. Phenotypic and molecular characterization of erythromycin resistance in four isolates of Streptococcus-like gram-positive Cocci causing bacteremia. J Clin Microbiol 42, 3303-3305. 


\title{
초록 : 임상미생물 검출을 위한 광대한 범위와 특이도를 가지는 $16 S$ rRNA PCR법 개발
}

\author{
김현철 ${ }^{1,2} \cdot$ 김윤태 ${ }^{1} \cdot$ 김효경 ${ }^{1}$ 이상후 ${ }^{1}$ 이경률 ${ }^{1} \cdot$ 김영진 $^{1 *}$ \\ ${ }^{1}($ 재 $)$ 서울의 과학연구소 분자생물연구팀, ${ }^{2}$ 연세대학교 생물소재공학 협동과정 $)$
}

$16 \mathrm{~S}$ rRNA gene PCR법은 환자 검체로부터 병원성 미생물을 검출 및 동정에 사용되어진다. 본 연구는 대량의 임상미생물 진단을 위해 bacterial $16 \mathrm{~S} \mathrm{rRNA}$ 부위 유전자 서열을 이용하여 광대한 범위와 높은 특이도를 가지는 primer을 포함한 PCR법을 개발하였다. 10 개 표준 균주 $16 \mathrm{~S}$ rRNA 보존 부위의 유전자 서열을 기반으로 primer set를 구축하였다. 98 명 환자 검체에서 임상 미생물을 분리하였다. 98 개 균주는 phenotypic 방법을 이용하여 확인 하고, 개발된 primer set와 universal primer set를 이용한 PCR법으로 확인하였다. 획득한 PCR 산물은 forward primer, reverse primer, 그리고 자동화 DNA 분석기를 이용하여 각 균주의 $16 \mathrm{~S}$ rRNA 유전자 서열을 분석 및 확인하였다. 본 연구에서 개발된 primer set와 universal primer set의 임상미생물 검출에 대한 효율성을 평가하였 고, 또한 phenotypic 방법과 분자생물학적 방법을 비교했다. 분리된 98 개 균주를 대상으로 개발된 primer set로 $16 \mathrm{~S}$ rRNA PCR을 진행하여 $778 \mathrm{bp}$ 크기의 단일밴드로 증폭 되었음을 확인했다. 총 98개중 94개 균주(95.9\%)는 phenotypic 결과와 동일함을 확인했다. 새로 개발된 primer set를 이용한 결과는 universal primer set를 이용한 98 개 균주 $(100 \%)$ 의 결과와 동일함을 확인하였다. 개발된 $16 \mathrm{~S}$ rRNA gene PCR법은 임상미생물 검출 및 동정에서 신속성, 정확성, 그리고 검사 비용 절감의 장점을 가진다. 개발된 primer set는 병원성 미생물 동정에서 효율성을 확인했다. 